\title{
RELATIONSHIP BETWEEN SURGICAL PROCEDURE AND OUTCOME FOR PATIENTS WITH GRADE I CHONDROSARCOMAS
}

Maurício Etchebehere, Olavo Pires de Camargo, Alberto Tesconi Croci, Claudia

Regina C. M. Oliveira, and André Mathias Baptista

ETCHEBEHERE M et al. Relationship between surgical procedure and outcome for patients with grade I chondrosarcomas. CLINICS 60(2):121-126, 2005.

PURPOSE: To evaluate the oncological outcome of patients with grade I chondrosarcomas according to the type of surgical treatment performed, since there is still controversy regarding the need for aggressive resections to reach a successful outcome.

MATERIALS AND METHODS: The records of 23 patients with grade I chondrosarcomas were reviewed. The mean age was 38.4 years, ranging from 11 to 70 years; $52 \%$ were men and $48 \%$ were women. The femur was the site of 13 tumors. The tumors were staged as IA $(17,74 \%)$ and IB $(6,26 \%)$. Regarding tumor location, $74 \%$ (17) were medullary, 22\% (5) were peripheral, and $4 \%$ (1) was indeterminate. Tumor size ranged from 2 to $25 \mathrm{~cm}$, mean $7.9 \mathrm{~cm}$. Regarding the surgical procedure, 11 patients underwent intralesional resection, 9 patients underwent wide resection, and 3 underwent radical resection. The follow-up period ranged from 24 to 192 months.

RESULTS: None of the patients developed local recurrence or metastases; 7 patients had other general complications. CONCLUSIONS: This data supports the use of less aggressive procedures for treatment of low-grade chondrosarcomas.

KEYWORDS: Chondrosarcoma. Treatment outcome. Curettage.

Chondrosarcoma is the second most frequent bone sarcoma, occurring mainly in the fourth and fifth decades. ${ }^{1}$ Classic chondrosarcomas can be divided into grades I, II, and III. ${ }^{2}$ Other histological types include juxta-cortical, clear cell, mesenchymal, and dedifferentiated chondrosarcomas. Chondrosarcomas may be classified as medullary or peripheral, according to the position in relation to the medullary bone. Chondrosarcomas can also be classified as primary or as secondary when it originates from a previously benign cartilaginous lesion.

A relationship between the prognosis and the histological grading and surgical treatment of chondrosarcomas has been identified. ${ }^{3,4}$ Surgery is the only effective method for

From the Division of Orthopaedic Oncology, Institute of Orthopaedics and Traumatology, University of São Paulo - São Paulo/SP, Brazil.

E-mail: mauricioe@ccot.med.br

Received for publication on June 17, 2004.

Accepted for publication on December 13, 2004. treatment of chondrosarcomas since these tumors do not respond to radiotherapy or chemotherapy. Grade I tumors have a better prognosis than grades II and III, with a lower incidence of metastases. 5,6

The presence of local recurrence and the type of surgical treatment have been correlated. Some authors do not recommend less aggressive surgical treatment because of the greater incidence of local recurrence. ${ }^{5,7-9}$ However, intralesional resection with the use of a local adjuvant (such as methyl-methacrylate) has been applied with good results in the treatment of aggressive borderline benign tumors such giant cell tumors of the bone. The same technique has been used in grade I chondrosarcomas in some situations. $^{10-12}$

The purpose of this study was to evaluate the oncological outcomes of patients with classic grade I chondrosarcomas compared to the type of surgery performed in order to evaluate the safety of the less aggressive procedures. 


\section{MATERIALS AND METHODS}

\section{Patient selection}

A restrospective analysis was performed on 39 patients with grade I chondrosarcomas as confirmed by histology. The histological analysis was reviewed by a pathologist experienced in bone pathology. Only patients with at least 24 months of postoperative follow-up (23) were included. Eleven patients were women and 12 were men. Patients' ages ranged from 11 to 70 years of age, mean age 38.4 years.

All tumors were surgically removed. Radiographs of the tumor site and thorax were performed on all patients in the follow-up period. The patients were followed up every 3 months during the first year, every 6 months during the second to fifth years, and every 12 months for up to 10 years after 5 years.

\section{Classification and staging}

Tumors were staged by the method described by Enneking et al. ${ }^{13}$ and accepted by the Musculoskeletal Tumor Society (MSTS). Tumors were also classified as medullary, peripheral, or indeterminate. The largest diameter of the tumor was determined for the evaluation of prognosis.

Preoperative staging for all patients consisted of chest and bone radiographies. One patient also had a preoperative skeletal CT scan, and 1 had a preoperative skeletal MRI.

\section{Surgical treatment}

The resections were either intralesional, wide, or radical. Intralesional resections were performed on 11 patients. This resection consisted of a simple curettage or was asso- ciated with local adjuvant (cauterization and use of methylmethacrylate) (Figure 1). Wide resection was performed in 9 patients and consisted of an in-block resection of the lesion with wide margins followed or not by implantation of an endoprosthesis. Radical resections were performed in 3 patients and consisted of 2 amputations and 1 total scapulectomy.

\section{Oncological analysis}

The oncological analysis was based on the presence of local recurrences, metastases, or death related to the tumor. It was classified as:

1. Alive and free of disease;

2. Alive with disease (local recurrence or metastasis);

3. Dead by disease;

4. Dead without disease.

\section{Statistical analysis}

The surgical procedures were divided into two groups: intralesional resections and wide/radical resections. The oncological results were compared between the two groups. The Fisher exact test and the Mann-Whitney test were used and the level of significance adopted was $5 \%$.

\section{RESULTS}

The median follow-up after surgery ranged from 24 to 192 months, mean 71.9 months, median 60 months. In the intralesional group the mean was 64 months, median 40 months. In the wide/radical group the mean was 79 months, median was 60 months $(P=.3)$. Five patients were lost to long-term follow-up: 1 at 51 months, 2 at 60 months, 1 at
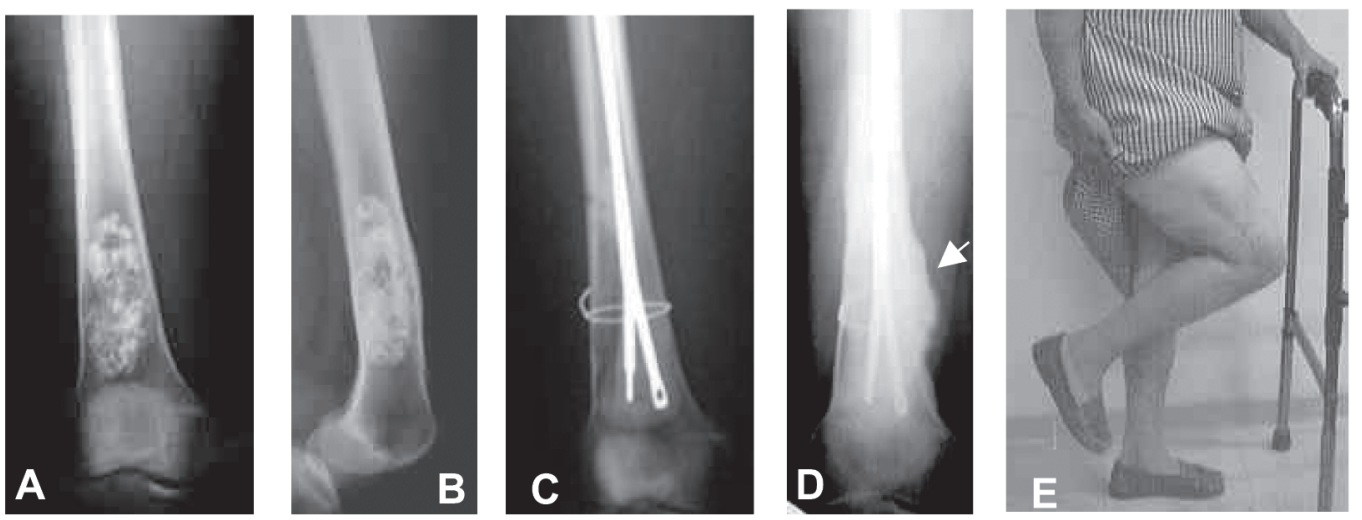

Figure 1 - Patient with a grade I chondrosarcoma who underwent an intralesional resection. A) and B) Preoperative radiograph of the distal femur showing well-organized calcific rings within the matrix and cortical bulging and endosteal erosion indicative of a low-grade chondrosarcoma. C) Postoperative radiograph. The tumor area was filled with methyl-methacrylate and Ender nails. D) One year after surgery; radiograph shows callus formation at the site of a non-displaced fracture that was treated conservatively. E) Functional aspect (knee flexion) of the surgically treated limb 1 month after surgery. 
84 months, and 1 at 120 months. Four of these patients were from the wide/radical group, and 1 patient was from the intralesional group (Table 1).

The most common location of the chondrosarcoma was the femur $(39 \%)$.

\section{Histopathology and classification results}

Seventeen patients $(74 \%)$ had medullary tumors, 5 patients $(21.7 \%)$ had peripheral tumors, and 1 patient had an indeterminate lesion. The largest diameter of the tumors ranged from $2 \mathrm{~cm}$ to $25 \mathrm{~cm}$, mean $7.9 \mathrm{~cm}$. The lesions were divided into 2 groups: 18 patients $(78 \%)$ had lesions smaller than $10 \mathrm{~cm}$, and 5 patients $(22 \%)$ had lesions larger than $10 \mathrm{~cm}$.

Seventeen lesions (74\%) were staged as IA and $6(26 \%)$ as IB.

\section{Surgical results}

Seven patients had postoperative complications. The most common complication was fracture (3/7 patients). These 3 patients had tumors in the distal femur, and the fractures occurred at the first, fifth, and twelfth postoperative months. One patient (1/7) had a loosening of the prosthesis in the distal femur 4 years after surgery. One patient (1/
7) had a deep venous thrombosis and a non-union at the site of tumor resection, also in the distal femur. One patient (1/7) developed hip pain with degenerative joint disease after an intralesional resection of a femoral head chondrosarcoma with electrical cauterization and filling with methyl-methacrylate. One patient (1/7) developed fibular neuropraxia with spontaneous regression after 4 postoperative months.

\section{Oncologic result}

All 23 patients were alive with no evidence of disease at the last follow-up. No patient needed resection of metastases or local recurrence during the follow-up period.

\section{DISCUSSION}

When Lichtenstein et al. ${ }^{14}$ established the criteria for differentiating benign from malignant cartilaginous tumors, they made it possible to grade chondrosarcomas and define the prognosis of each histological type. Depending on the histological type-I, II, or III-the surgical strategy will differ. However, prognostic analysis using histology type of chondrosarcomas is not adequate due to the distinct behavior and aggressiveness of each type, which may lead to erroneous results. Any study of chondrosarcomas should

Table 1 - Results with grade I chondrosarcomas regarding location, origin, staging, size, type of surgery, complications, follow-up time, and oncological and functional outcome.

\begin{tabular}{|c|c|c|c|c|c|c|c|c|}
\hline $\mathrm{N}^{\circ}$ & Location & Origin & Stage & Diameter $(\mathrm{cm})$ & Type of Surgery & Complications & Follow-up & Oncologic \\
\hline 1 & Phal & I & IB & -- & $\mathrm{R}$ & & 60 & A \\
\hline 2 & Prox & M & IA & 4 & $\mathrm{Cu}+\mathrm{LA}$ & $\mathrm{DP}$ & 192 & A \\
\hline 3 & Prox & $\mathrm{P}$ & IA & 6 & Wide & & 51 & A \\
\hline 4 & Prox & M & IB & 8 & Wide & neuropraxia & 154 & A \\
\hline 5 & Dist & M & IA & 6 & Wide + end & loosening & 144 & A \\
\hline 6 & Scap & $\mathrm{P}$ & IB & 25 & $\mathrm{R}$ & & 120 & A \\
\hline 7 & Dist & M & IA & 10 & $\mathrm{Cu}+\mathrm{LA}$ & & 60 & A \\
\hline 8 & Phal & M & IB & 6 & $\mathrm{R}$ & & 120 & A \\
\hline 9 & Dist & M & IA & 15 & $\mathrm{Cu}+\mathrm{LA}$ & fracture & 108 & A \\
\hline 10 & Diap & M & IA & 15 & $\mathrm{Cu}+\mathrm{LA}$ & & 84 & A \\
\hline 11 & Prox & M & IA & 11 & Wide + end & & 84 & A \\
\hline 12 & Prox & M & IA & 7 & Wide + end & & 60 & A \\
\hline 13 & Dist & M & IA & 5 & $\mathrm{Cu}+\mathrm{LA}$ & Fracture & 67 & A \\
\hline 14 & Dist & M & IA & 2 & Wide & DVT+DJD & 60 & A \\
\hline 15 & Dist & M & IA & 5 & $\mathrm{Cu}+\mathrm{LA}$ & & 29 & A \\
\hline 16 & Dist & M & IA & 10 & $\mathrm{Cu}+\mathrm{LA}$ & Fracture & 40 & A \\
\hline 17 & Dist & M & IA & 10 & $\mathrm{Cu}+\mathrm{LA}$ & & 29 & A \\
\hline 18 & Dist & M & IB & 2 & $\mathrm{Cu}$ & & 37 & A \\
\hline 19 & Isch & $\mathrm{P}$ & IB & 4 & Wide & & 39 & A \\
\hline 20 & Metat & $\mathrm{P}$ & IA & 3 & Wide & & 33 & A \\
\hline 21 & Prox & M & IA & 2 & $\mathrm{Cu}$ & & 35 & A \\
\hline 22 & Prox & $\mathrm{P}$ & IA & 16 & Wide & & 24 & A \\
\hline 23 & Prox & M & IA & 3 & $\mathrm{Cu}$ & & 24 & A \\
\hline
\end{tabular}

Source: IOT HC FMUSP. I = indeterminate ; $\mathrm{M}=$ medullary ; $\mathrm{P}=$ peripheral; Prox $=$ proximal femur $;$ Diap $=$ femoral diaphisis; Dist $=$ distal femur; Phal = phalanx; Scap = scapula; Isch = ischium $;$ Metat = metatarsal; $\mathrm{Cu}=$ curettage LA = local adjuvant; End = endoprosthesis; $\mathrm{R}=$ radical; DVT = deep venous thrombosis; DJD = degenerative joint disease; $\mathrm{A}=$ Alive and free of disease 
differentiate grade I lesions, which have a good prognosis.

However, the differentiation of each tumor grade is not an easy task. When biopsies are performed on chondrosarcomas, a correct diagnosis is reached in $96 \%$ of the cases, but the correct tumor grade only occurs in $46 \%$ of cases. ${ }^{15}$ Therefore, it is unsafe to use histology alone to plan treatment for patients with chondrosarcomas. ${ }^{15}$ The tumor must be considered malignant if the radiographic findings point to this, even when histology indicates otherwise. ${ }^{16}$ Clinical, radiographic, and histologic evaluations must be used together to define the tumor grade. ${ }^{8,10}$ The incisional biopsy is not necessary in all cases, but it should be performed when diagnosis is in doubt.

Medullary lesions relate to a higher incidence of metastases, but local recurrence is about the same as with peripheral lesions. ${ }^{5}$ Our data are similar to those of Bauer et al. ${ }^{10}$ in which the follow-up of 40 grade I medullary lesions showed only 3 local recurrences and no metastases. In the present series, no metastases or local recurrences occurred regardless of the medullary or peripheral nature of the lesions.

Neither has a relationship of tumor size to survival been clearly established. Lower survival rates in 113 patients with pelvic or proximal femoral chondrosarcomas larger than 13 $\mathrm{cm}^{17}$ and in patients with tumors larger than $10 \mathrm{~cm}^{6,18}$ have been reported. However, in a study of pelvic chondrosarcomas, tumor size did not influence the occurrence of metastases. ${ }^{19}$ In another study of grade I chondrosarcomas with lesion sizes ranging from 1 to $40 \mathrm{~cm}$, there were 3 local recurrences in tumors smaller than $10 \mathrm{~cm}$. In the present study, tumor size was evaluated by measuring the largest diameter of the lesion, which is the current procedure. ${ }^{10,17-}$ 19 Tumor size did not influence patient prognosis, and no local recurrences occurred in spite of the size ranging from 2 to $25 \mathrm{~cm}$.

A relationship between the incidence of recurrences and the location of the primary lesion has also not been established. In the study of 40 patients with grade I chondrosarcomas, local recurrences occurred in 1 of 5 extracompartmental lesions and 2 of 35 intracompartmental lesions. ${ }^{10}$ In a study of 14 patients with grade I chondrosarcomas, local recurrence was observed in 7 of 11 extracompartmental lesions, 2 of 2 intracompartmental lesions, and in 1 of 1 indeterminate lesion. ${ }^{20}$ In another study of 17 patients with grade I chondrosarcomas, only one local recurrence was noted, and it occurred in an intracompartmental lesion. ${ }^{8}$ In the present study in which 6 tumors were extracompartmental and 16 were intracompartmental, no local recurrence or metastases occurred; therefore, the location of the primary tumor did not influence the clinical outcome.
There is not a consensus regarding the amount of follow-up time required after surgery regarding patients with chondrosarcomas. Some authors assert that a follow-up of 2 years is adequate, while others consider a of 5 years as a minimum. 5,10,17,19,21,22 Recurrences and metastases in lowgrade lesions occur less frequently for the first time after 5 years, and the possibility of metastases occurring before a local recurrence is very low.$^{5,6,23}$ In a study of 40 patients with grade I chondrosarcomas, recurrence occurred in 3 patients, 1, 3, and 6 years after surgery. ${ }^{10}$ In a second study of patients with grade I pelvic chondrosarcomas, recurrences occurred on average 77 months after surgery, but no metastases were detected. ${ }^{19}$ In a third study, patients with grade I chondrosarcomas undergoing intralesional resections, it was found that 10 patients experienced recurrence, 7 of them before 5 years of follow-up. ${ }^{20}$ In a fourth study, in patients with grade I chondrosarcomas, a mild change in recurrence after 5 years of follow-up was detected. ${ }^{24}$ Therefore, patients with grade I chondrosarcomas must be followed-up for at least 5 years, preferably for 10 years. The analysis of this series will probably experience some mild alterations after 5 years of minimum follow-up because in this series the minimum follow-up is 2 years with an average of 6 years.

Chondrosarcomas have a poor response to radiotherapy and chemotherapy. This may be explained by the fact that its growth is mainly due to matrix production and not so much to DNA replication. ${ }^{8}$ This is probably one of the reasons why surgery is the treatment of choice and the type of resection is a determining factor in prognosis. ${ }^{6,8,9,18,21}$

The terms adequate or inadequate surgical procedures have been regarded as important factors influencing prognosis in chondrosarcomas. ${ }^{2}$ An inadequate surgical procedure refers to a surgery in which there is violation of the tumor bed and contamination. Some authors report that an inadequate surgical procedure increases the risk of recurrence and metastases. ${ }^{5-7,19,21,22,25}$ However, the presence of a local recurrence of a grade I chondrosarcoma presents a low risk of developing metastases. ${ }^{9,10,19,20,23}$ Therefore, a local recurrence in grade I chondrosarcomas does not represent a poor prognosis, especially when it occurs in the lower extremities because of the possibility of resection. Therefore, many authors propose that less aggressive surgical treatment of grade I chondrosarcomas will not compromise the prognosis. ${ }^{10,12,20,22}$

The good oncological result obtained in this series of patients undergoing intralesional resections shows that this is a valid form of treatment for medullary grade I chondrosarcomas, as has been demonstrated by other authors. ${ }^{12,26}$ In this series, 3 patients were treated only with curettage without the use of adjuvant therapy and did not experience 
recurrence after 24, 35, and 37 months of follow-up. These good outcomes brings into question the malignant nature of these lesions, similarly to the reported series of 23 patients undergoing intralesional resection with only 2 recurrences. $^{10}$

An important issue is whether the functional results obtained through intralesional resection justify its use in cases of grade 1 chondrosarcomas, especially in regions frequently involved, such as the distal femur and proximal humerus, in which wide resections and placement of endoprosthesis seem too aggressive. Bauer et al. ${ }^{10}$ conclude that the more aggressive procedure results in considerable morbidity and therefore should only be performed in tumors with a higher risk of local recurrence or metastases, which is not the case in grade I chondrosarcomas.

The most frequent complication was fracture. In spite of the fact that the fractures occurred in the distal femur, the correlation between fracture and location was not significant, since the distal femur was also the most frequent site of the tumor. Also the complication rates did not differ between group receiving intralesional resections and that receiving wide/radical resections.
There was a tendency towards better functional results with the intralesional resections, possibly because the procedure is less aggressive with greater preservation of the adjacent tissue. However this relationship could not be proven because of the small number of patients who had tumors located in many different locations, making the function analysis impossible.

Good results, as described in this series, require the elimination of tumor cells in the region adjacent to the tumor, which is accomplished by resection of the tumor margins, but by a simple inadequate intralesional resection. Our findings indicate that less aggressive procedures, such as intralesional resections with local adjuvants, can be safe for treatment of lowgrade medullary grade I chondrossarcomas and may be the method of choice in non-expendable bones. The medullary chondrosarcomas located in expendable bones such as the proximal fibula, iliac wing, and clavicle can be resected in block. The same technique is indicated for peripheral grade I chondrosarcomas. A longer follow up and a meta-analysis including many papers probably will confirm that the in-block resections are not the best treatment of grade I medullary chondrosarcomas in non-expendable bones.

\section{RESUMO}

ETCHEBEHERE M e col. Evolução dos pacientes com condrossarcoma grau I em relação ao tipo de tratamento cirúrgico. CLINICS 60(2):121-126, 2005.

OBJETIVO: Avaliar a evolução oncológica de portadores de condrossarcomas grau I de acordo com o tipo de tratamento cirúrgico efetuado. Existe controvérsia em relação à necessidade de ressecções agressivas para obtenção de uma evolução clínica favorável.

MATERIAIS E MÉTODOS: Os prontuários de 23 portadores de condrossarcoma grau I foram analisados. A idade dos pacientes variou de 11 a 70 anos com média de 38,4 anos, $52 \%$ eram homens e $48 \%$ mulheres. O local mais acometido foi o fêmur com 13 pacientes. Dezessete lesões $(74 \%)$ foram classificadas como IA e seis $(26 \%)$ como IB.
Setenta e quatro por cento dos tumores eram medulares, $22 \%$ eram periféricas e uma lesão indeterminada. O tamanho dos tumores variou de 2 a $25 \mathrm{~cm}$, média de 7,9 $\mathrm{cm}$. Onze pacientes foram submetidos a ressecção intralesional, nove a ressecção ampla e três a ressecção radical. O seguimento variou de 24 a 192 meses.

RESULTADOS: Complicações não oncológicas ocorreram em sete pacientes. Nenhum dos pacientes apresentou recidiva local ou metástase. Estes dados sugerem que os procedimentos cirúrgicos menos agressivos são seguros para o tratamento dos pacientes com condrossarcoma grau I.

UNITERMOS: Condrossarcoma. Resultado de tratamento. Curetagem.

\section{REFERENCES}

1. Dorfman HD, Czerniak B. Bone cancers. Cancer 1995;75:203-10. Supplement.

2. Dahlin DC, Henserson ED. Chondrosarcoma, a surgical and pathological problem. Review of 212 cases. J Bone Joint Surg [Am] 1956;38:1025-238.
3. O'Neal LW, Ackerman LV. Chondrosarcoma of bone. Cancer 1952;5:551-77

4. Roberg OT. Chondrosarcoma. Relation of structure and location to the clinical course. Surg Gynecol Obstet 1935;61:68-82. 
5. Gitelis S, Bertoni F, Picci P, Campanacci M. Chondrosarcoma of bone. The experience at the Instituto Ortopedico Rizzoli. J Bone Joint Surg [Am] 1981;63:1248-57.

6. Pritchard DJ, Lunke RJ, Taylor WF, Dahlin DC, Medley BE. Chondrosarcoma: a clinicopathologic and statistical analysis. Cancer 1980;45:149-57.

7. Dahlin D, Salvador AH. Chondrosarcomas of bones of the hands and feet. A study of 30 cases. Cancer 1974;34:755-60.

8. Eriksson AI, Schiller A, Mankin HJ. The management of chondrosarcoma of bone. Clin Orthop 1980;153:44-66.

9. Evans HL, Ayala AG, Romsdahl M. Prognostic factors in chondrosarcoma of bone. A clinicopathologic analysis with emphasis on histologic grading. Cancer 1977;40:818-31.

10. Bauer HCF, Brosjö O, Kreicbergs A, Lindholm J. Low risk of recurrence of enchondroma and low-grade chondrosarcoma in extremities. 80 patients followed for 2-25 years. Acta Orthop Scand 1995;66:283-88.

11. Camargo OP. Tratamento cirúrgico do tumor de células gigantes através da ressecção marginal e colocação de metilmetacrilato. São Paulo, 1994. (Livre Docência - Faculdade de Medicina da Universidade de São Paulo).

12. Hiz M, Erdogan F, Blazig N, Dervisoglu S, Kanberoglu K. Curettage and cementation in the treatment of grade I chondrosarcoma. In: Combined meeting of the Americam and European musculoskeletal tumor societies, 4. Proceedings. Washington: Americam and European Musculoskeletal Tumor Societies; 1998. p.166.

13. Enneking WF, Spanier SS, Goodman MA. A system for the surgical staging of musculoskeletal sarcoma. Clin Orthop 1980;153:10620 .

14. Lichtenstein L, Jaffe HL. Chondrosarcoma of bone. Am J Pathol 1943;19:553-89.

15. Etchebehere M, Camargo OP, Croci AT, Oliveira, NRB, Oliveira CRCM, Baptista AM. O papel da biópsia percutânea prévia no diagnóstico histológico definitivo na suspeita de lesões catilaginosas malignas do esqueleto. Rev Bras Ortop 1999;34:77-80.
16. Ogose A, Unni KK, Swee RG, May GK, Rowland CM, Sim FH. Chondrosarcoma of small bones of the hands and feet. Cancer 1997;80:50-9.

17. Marcove RC, Miké V, Hutter RVP, Huvos AG, Shoji H, Miller TR, Kosloff R. Chondrosarcoma of the pelvis and upper end of the femur. An analysis of factors influencing survival time in one hundred and thirteen cases. J Bone Joint Surg [Am] 1972;54:561-72.

18. Larsson SE, Borssén R, Lennart B. Chondrosarcoma. A multifactorial clinical and histopathological study with particular regard to therapy and survival. Int Orthop 1979;2:33341 .

19. Sheth OS, Yasco AW, Johnson ME, Ayala AG, Murray JA, Romsdahl MM. Chondrosarcoma of the pelvis. Prognostic factors for 67 patients treated with definitive surgery. Cancer 1996;78:74550 .

20. Ozaci T, Lindner N, Hillmann A, Rödl R, Blasius S, Winkelmann W. Influence of intralesional surgery on treatment outcome of chondrosarcoma. Cancer 1996;77:1292-7.

21. Henderson ED, Dahlin DC. Chondrosarcoma of bone. A study of two hundred and eighty-eight cases. J Bone Joint Surg [Am] $1963 ; 45: 1450-8$.

22. Sanerkin NG, Gallagher P. A review of the behavior of chondrosarcoma of bone. J Bone Joint Surg [Br] 1979;61:395400 .

23. Azzarelli A, Gennari L, Quagliuolo V, Bonfanti G, Cerasoli S, Bufalino R. Chondrosarcoma-55 unreported cases: epidemiology, surgical treatment and prognostic factors. Eur J Surg Oncol 1986;12:165-8.

24. Huvos AG, Marcove RC. Chondrosarcoma in the young. A clinicopathologic analysis of 79 patients. Am J Surg Pathol 1987;11:930-42.

25. Barnes R, Catto M. Chondrosarcoma of bone. J Bone Joint Surg [Am] 1966;48:729-64.

26. Marcove RC, Stovell PB, Huvos AG, Bullough PG. The use of cryosurgery in the treatment of low and medium grade chondrosarcoma. Clin Orthop 1977;122:147-56. 